\title{
ON SOME CAVE MINERALS FROM NORTHERN NORWAY
}

\author{
Bogdan Petroniu Onac ${ }^{*} \&$ Stein-Erik Lauritzen ${ }^{\S}$
}

\begin{abstract}
The present paper aims to point out the results of 31 samples from some Norwegian caves that have been analysed with respect to their mineralogical composition. Identification of the minerals were done by X-ray diffraction, thermal, infrared spectroscopy and scanning electron microscopy. Seventeen minerals were identified belonging to 4 groups: carbonates, sulphates, oxides-hydroxides and silicates.
\end{abstract}

RESUME (Sur quelques mineraux de grotte dans la Norvège Septentrionale)

Le travail presente les resultats de l'etude mineralogique de 31 echantillons provenant de plusieurs grottes -de la Norvege. Par suite des analyses en rayons $\mathrm{X}$ infra-rouges, thermiques et de microscopie électronique a balayage, on a identifie 17 mineralLx appartenant a quatre groupes principaux: carbonates, sulfates, oxyhydroxydes et silicates.

\section{INTRODUCTION}

The most representative karst phenomenona in Norway are to be found around and above the Arctic Circle, being developed in metamorphic marbles and dolomites (Lauritzen, 1991). The karst landscape from north Norway offer an overwhelming variety of morphological features on all scales, which have resulted in a wide range of publications within geomorphology, hydrology, sedimentology and chronology.

Cave minerals have not previously been described in detail. The cold conditions of Norwegian caves associated with a variety of minerals interbedded in layers with the marble strata, and an extremely diverse petrography of the rocks which come in contact with the marbles could provide favorable conditions for the formations of a large variety of cave minerals. The present paper presents the analysis of 31 mineral samples from 15 locations.

Due to the cold conditions and high latitude, speleothems are rare in Norwegian caves when compared with caves from temperate zones. This is in part due to climatic (temperature, $\mathrm{PcO}_{2}$ ) controls (Ford \& Williams, 1992), and to lithofacial factors (Onac, 1991).

The name and location of the sarnpled caves are withheld for conservational reasons.

\section{MINERALOGICAL ASPECTS}

Thirty-one samples from different Norwegian caves had been analysed so far in respect to their mineralogical composition. X-ray diffraction (XRD), as well as thermal, infrared spectroscopy (IR) and scanning electron microscopy (SEM) were used for this purpose. The analysis were done in two different laboratories belonging to the University of Bergen (Norway) and University of Cluj (Romania) using Philips and JEOL devices assisted by computers.

\footnotetext{
*"Babeș-Bolyai" University, Department of Mineralogy, Kogălniceanu 1, 3400 CLUJ (Romania).

${ }^{\S}$ Bergen University, Geology Dept., Allégt. 41, N-5007 BERGEN (Norway).
} 
Normally, three main categories of minerals are found in caves: (1) allogenic minerals, transported into the cave by mechanical action of gravity, water or wind, (2) authogenic residual minerals (fragments of bedrock, minerals formed during petrogenesis and debris left behind from the dissolution processes) and (3) authogenic precipitates formed in situ by chemical processes in the cave system. Our paper deals mostly with the latter one.

\section{l. Carbonates}

Calcite is by far the most common carbonate mineral in the Norwegian caves, being the stable form of calcium carbonate under the temperature, total pressure and $\mathrm{CO}_{2}$ partial pressure of the cave environment. Aragonite and hydromagnesite can be found as well.

Calcite frequently appears to occur as a single mineral which exhibit almost infinitely varied morphologies. The most representative are flowstone, dripstone, rimstone, pool deposits and moonmilk. All of these form in almost any cave.

Moonmilk is a very common speleothem in many Norwegian caves (Onac, 1991). It is a soft, white (sometimes white-yellowish) mixture of microscopic crystals of different carbonates or sulphates with an important amount of water (Hill \& Forti, 1986). The moonmilk samples we analysed were mostly calcitic and in just one case we found hydromagnesite and gypsum. As shown by SEM (Fig. 1) the calcite crystals appear to form either fibrous-lamellar or acicular-prismatic microcrystals.

In a previous paper, Onac \& Farcas (1992), pointed out large moonmilk deposits located along well ventilated galleries, which are composed entirely of thread-shaped crystals (fibrous-lamellar or acicular prismatic) (Bernasconi, 1975) in size between 8 and

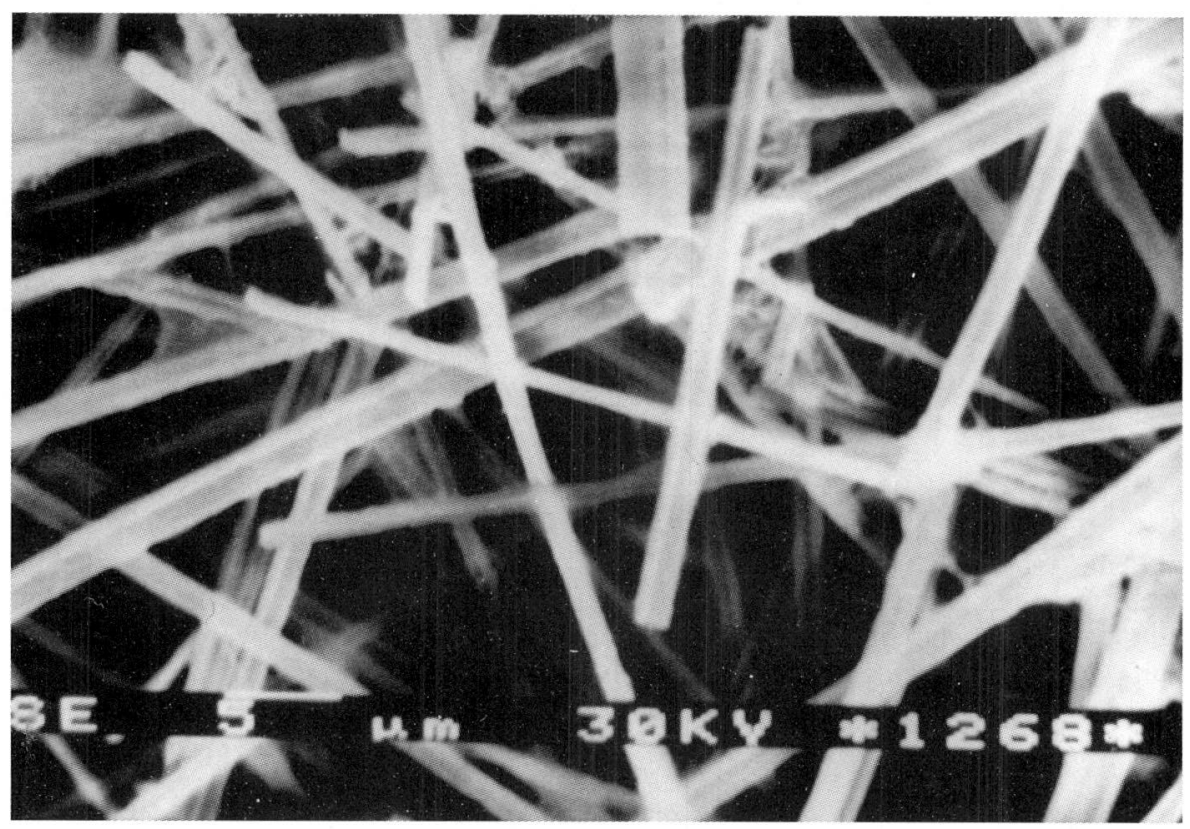

Fig. 1 - SEM. Calcitic moonmilk; the acicular crystals are developed parallel to the c-axis (sample 749). 
$80 \mu \mathrm{m}$ in length and $0.1-2 \mu \mathrm{m}$ in thickness. A primary origin (Diaconu, 1976) was ascribed to these deposits which have been precipitated directly from super-saturated solutions. The moonmilk which has been sampled from dry cave passages consist of paramorphs of calcite after aragonite and more often a consolidation of moonmilk

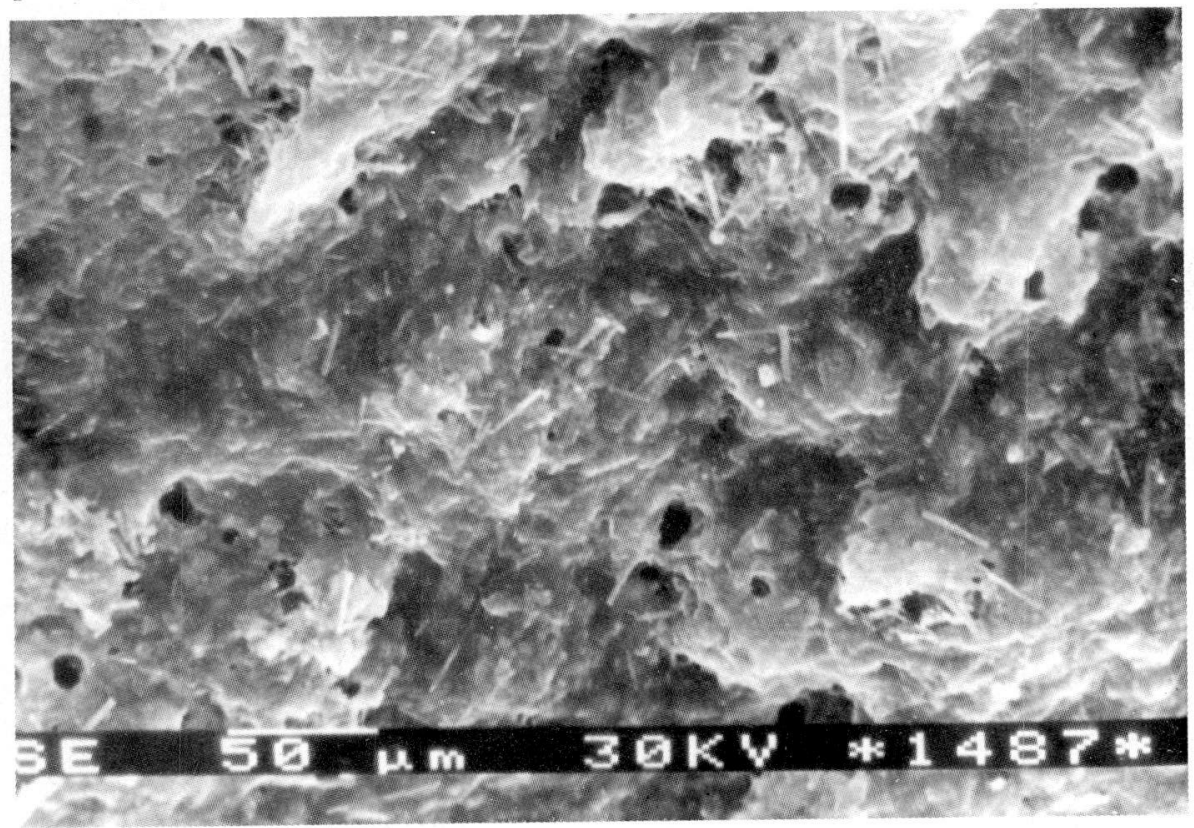

Fig. 2 -SEM. Moonmilk in which calcite crystals suffered a cimentation process (sample 810).

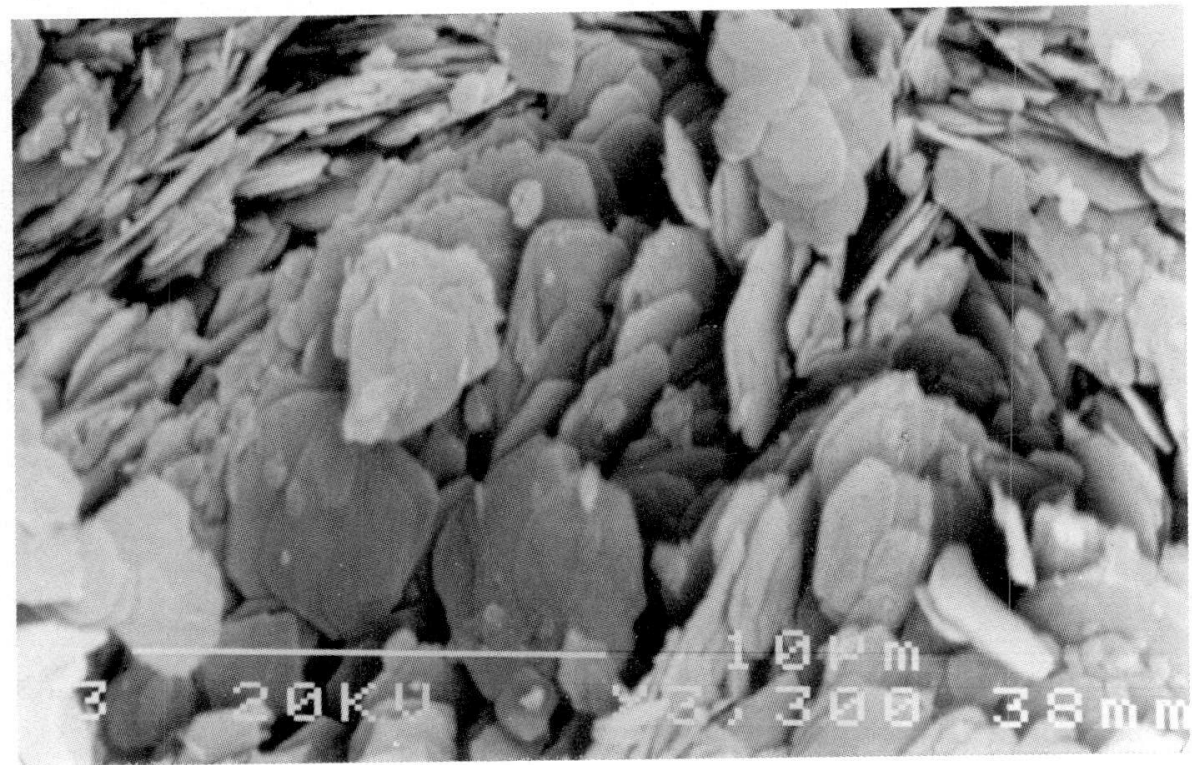

Fig. 3 - SEM. Lamellar aggregates of hydromagnesite (sample 764). 
aggregates by new forming calcite is seen (Fig. 2). The cave ventilation has a major influence on the dynamics of the precipitation processes by setting up local thermodynamic conditions. The morphological differences we noticed among calcite crystals composing our sampled moonmilk reflect these various thermodynamic conditions (Onac \& Ghergari, 1993).

In a moonmilk-like sample collected from behind some "gypsum balloons" we found hydromagnesite. It forms very thin scaly crystals arranged in the shape of flakes (Fig. 3), showing symmetric extinction and positive elongation (Onac \& Ghergari, 1993). Mirror-image twins on (100) with elongate lamellae along the c-axis have also been observed.

White, powdery deposits (on the cave floor) of hydromagnesite were also observed in one cave. We believe that the occurence of hydromagnesite can be explained either by seepage of magnesium-rich solutions into the cave, when soft moonmilk precipitate or by magnesium waters seeping up through cave soil with deposition of white earthy-like deposits.

The mineralogical investigations carried out on some light-gray, well crystallized crusts, have pointed out microaggregates of acicular crystals which were analysed by means of XRD technique. The spectrum (Fig. 4) indicated the presence of aragonite. Closely associated with aragonite, we found tabular gypsum crystals.

Aragonite can nucleate and grow quite easily when the necessary supersaturation

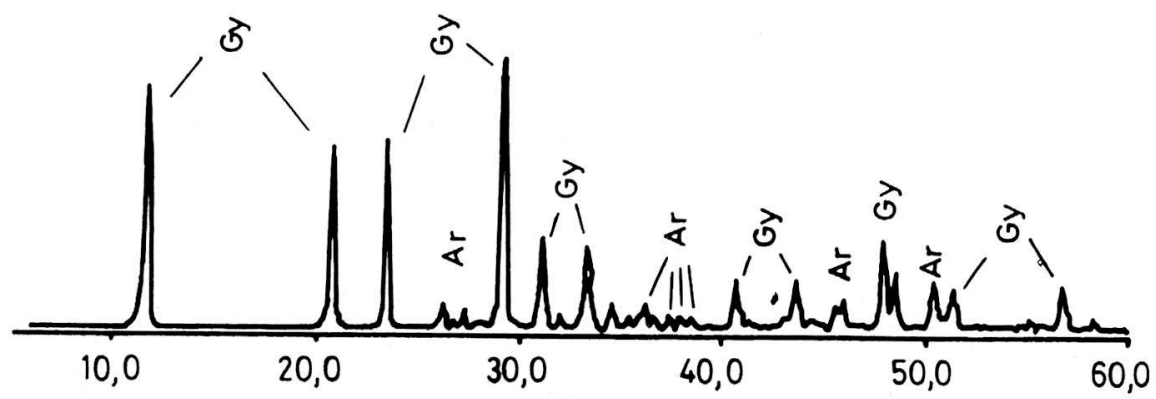

\section{Gy=Gyps um, Ar =Aragonite}

Fig.4 - XRD spectlum of aragonite from sample 768.

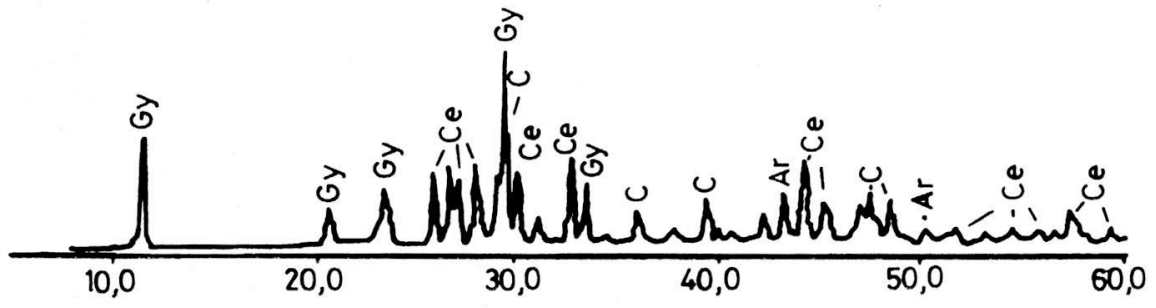

Ce=Celestite, $G y=$ Gypsum, $C=$ Calcite,$A r=$ Aragonite

Fig. 5 - XRD spectrurn of white crystalline powder (sample 771). 


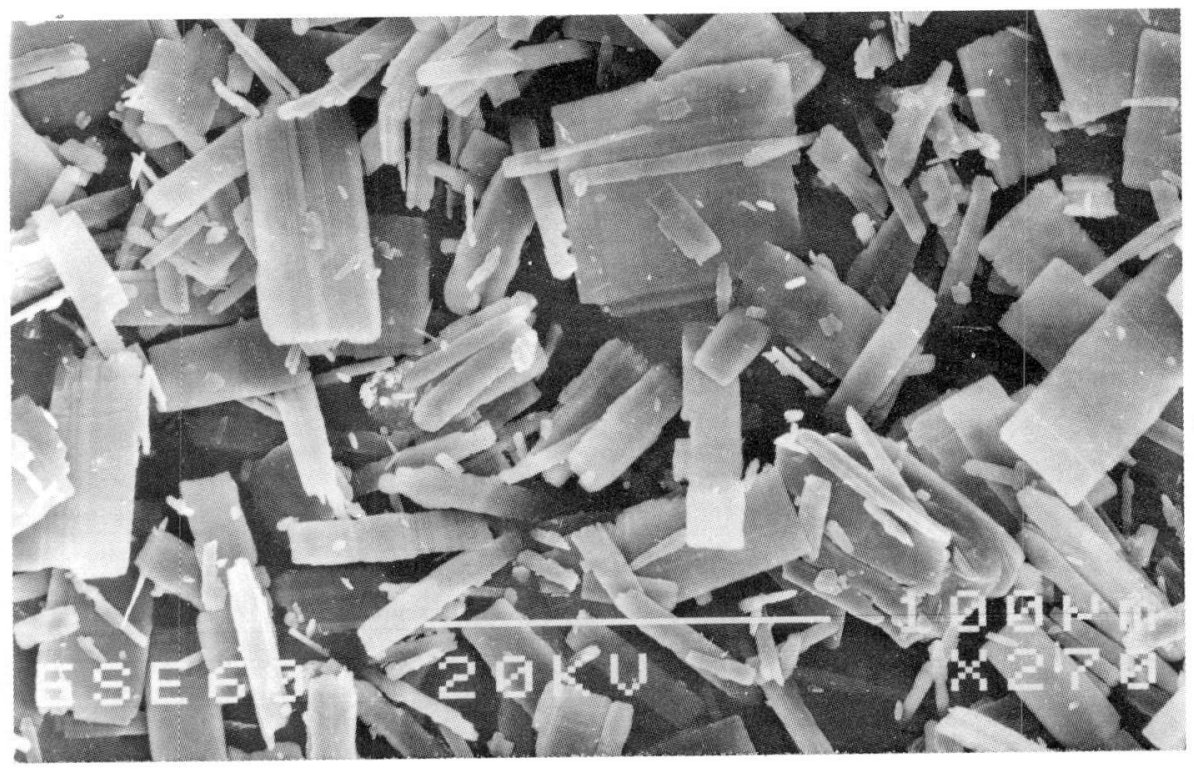

Fig.6 - SEM. Gypsurn moonmilk; lamellar crystals (sample 765).

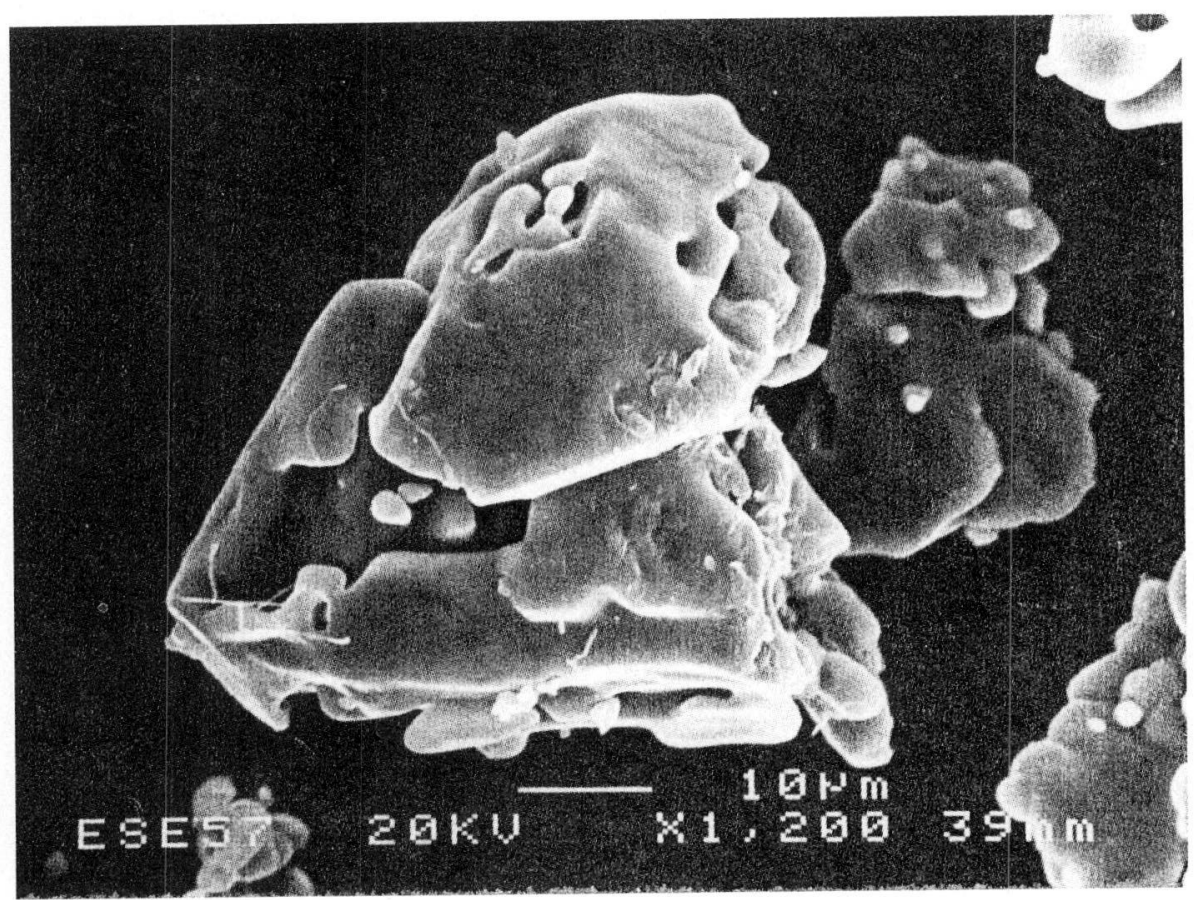

Fig. 7 - SEM. Tabular crystals of thenardite (sarnple 766). 
level is attained and when the growth of calcite is suppressed. For this it seems that the magnesium, strontium and sulfate ions must poison the crystal growth of calcite, to allow the supersaturation level where aragonite can precipitate (White, 1976). Of these ions, sulfate (in gypsum) and magnesium (from wall-rock) are present in the close vicinity and can be the prime factor influencing aragonite deposition in preference to calcite deposition.

\section{Sulphates}

Among sulphate minerals, gypsum is very common in many Norwegian caves, as our analysis pointed out. Three forms are present: (1) gypsum crusts, (2) euhedral crystals grown in a clay matrix and (3) gypsum moonmilk.

Both granular and fibrous crust varieties have been found: the latter often display thin-walled semispherical balloon-like crust, several centimeters across. Behind these balloons a white crystalline powder was collected. The XRD spectrum (Fig. 5 ) indicated a mixture of celestite and gypsum crystals. To confirm the identification of celestite we have made some observation at the polarizing microscope. Transparent to translucent celestite grains, with vitreous to pearly luster having strong relief (when compared with gypsum) were observed. It seems that celestite has been precipitated by percolating waters carrying strontium in solution leached from the wall rocks.

Euhedral gypsum crystals take a columnar shape (001), sparsely prismatic, usually perfectly transparent. Sometimes they are slightly coloured by fine grains of clay. Needle-like and sword crystals are to be found penetrating the clay layer's surface. Their size do not exceed $1 \mathrm{~cm}$ in lenght and $0.2-1 \mathrm{~cm}$ in thickness.

The gypsum moonmilk consists of lamellar microcrystals with silky lustre that form delicate aggregates having different habits and sizes (0.1-1.5 mm $\varnothing)$. Closely associated with gypsurn we found large grains with dull lustre ascribed to calcite. The crystals'

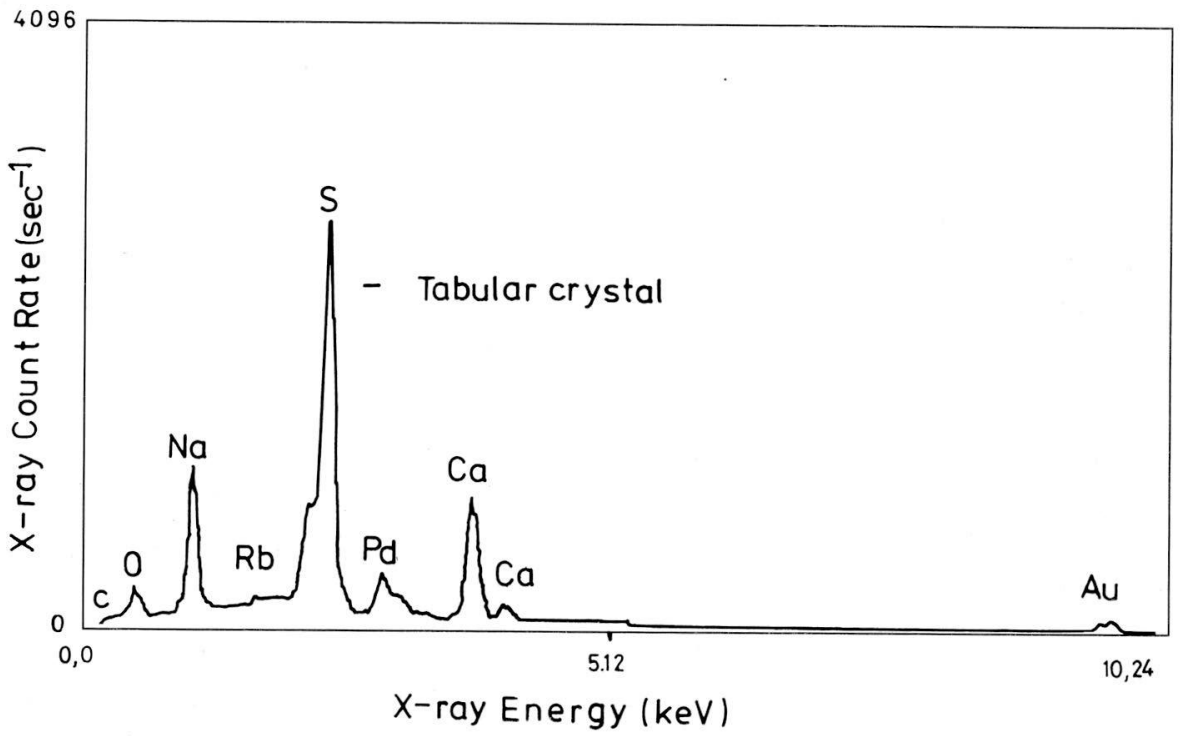

Fig.8 - IDX Spectrum of thenardite from sample 766 
morphology analysed by SEM (Fig. 6) showed that gypsum is a neomorphic mineral having euhedral habit (grains displaying fully developed crystal form) while the calcite appears as relict clasts (grains that present corroded edges).

The other sulphate mineral we found is thenardite; this mineral is stable in a dry cave environment (for more details see Hill \& Forti, 1986, p.114). Thenardite was first time seen as white microcrystalline aggregates spread over a thick porous floor soil deposit that covers one room, often used by speleologists as a camp site. SEM analysis of this microcrystalline rnaterial showed an aggregate consisiting of tabular crystals, developed parallel to (001) with more or less corroded edges (Fig. 7). The EDX spectrum irrefutably proved the presence of this mineral (Fig. 8).

Due to the high level of human impact (camping and cooking), in this place the humidity is well under the normal values which characterize the cave environrnent (over $90 \%$ ) being possible for this reason a direct precipitation of thenardite. In most of the caves where this mineral was found (except lava tubes), originally, precipitated as mirabilite and dehydrating to thenardite when the cave environment became drier.

We consider oxidation of sulphides (i.e. pyrite and marcasite, especially) locally within the cavernous limestone, as well as, oxidation of sulphides from elsewhere in the stratigraphic section and transport into the cave by percolating water to be the main

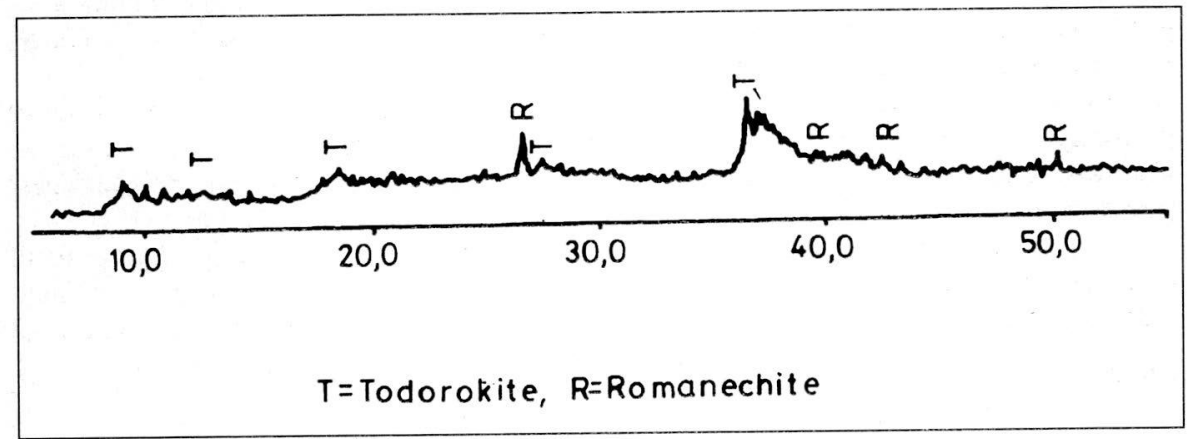

Fig. 9 -XRD spectrum of todorokite from sample 808a.

sources of $\mathrm{SO}_{4}^{2-}$. No exhaustive investigations have been done with respect to the presence of thenardite, but the following mechanism can be possible: an interaction between the cave floor sediments with high content of muscovite and orthoclase which could provide $\mathrm{Na}^{+}$and sulphate solutions moving upwards through that porous cave soil.

\section{Oxides and Hydroxides}

In a cave environrnent, $\mathrm{pH}$ is generally between 7 and 8 (with few exceptions), Eh is in the range of +0.4 to +0.6 volts (oxidizing) and activity of water is near unity (Hill \& Forti, 1986). With respect to this situation, the stable form of iron is a ferric hydrate and for manganese a mixed $\mathrm{Mn}^{3+}$ and $\mathrm{Mn}^{4+}$ oxide. Because these compounds are highly insoluble they tend to appear as crusts and coatings but generally do not form speleothems themselves.

We sampled from different caves dull opaque, brownish-black to black crusts looking very similar to what we know to be called wad. Our analysis revealed the sarne composition as in most of the references (e.g. Kashima, 1983). "Wad" is typically a finegrained mixture, chiefly pyrolusite and romanechite, both being identified through 
$\mathrm{XRD}$ analysis in our samples as well. Another complex hydrous manganese oxide was identified by laboratory study (chemical, XRD and IR) to be todorokite (Fig. 9).

Their presence in caves can be ascribed to the weathering process of manganeous carbonates or silicates which are common in the surounding area of the sampled caves. Bacteria may also play a part in their genesis (Coman, 1984).

Reddish-brown to brownish-yellow coatings and small rimstone dams made up of goethite are to be found in many caves covering either calcite or sand speleothems. Most of the common yellow-brown ferric oxides usually known as limonite properly belong to this species. Limonite is usually associated with acidic groundwaters. Limonite and goethite speleothems occur in caves where the cavernous limestone underlies ironbearing rocks or where rich iron rock lenses are to be found interbedded in marble. Oxidation of siderite and pyrite-rich horizons produces acidic solutions which can retain the iron in solution. When these solutions are neutralized after they have percolated downward into the cavernous limestones, the iron is precipitated. Limonite and goethite can be transported in suspension as colloids or as very fine-grained particles until the material accumulates in dripstone deposits. All minerals ascribed to this group, mentioned until now, forrned under oxidizing conditions.

The crystalline forms of solid water (ice) belong as well to the oxide rninerals. Given the high latitude of the Norwegian karst, and because of the mean annual temperature that in some places falls below $0^{\circ} \mathrm{C}$, both ephemeral ice, forrning in the entrance passages of caves during the cold seasons and perennial ice occuring when special airflow conditions maintain low ternperatures during the warm season, are to be found.

The variety of ephemeral ice speleothems is very rich, although not as rich as that of calcite speleothems. They resemble one another in many ways, especially where the forms are the direct result of flowing water (stalactites, stalagmites, ice falls).

Caves containing perennial ice are known as glaciéres. The ice stratigraphy could provide extremely important paleoenviromnental informations by using ${ }^{14} \mathrm{C}$ to date organic matter lenses (wood, bone, etc.) that are interbedded in the ice. Measuring $\mathrm{d}^{18} 0$ of the formation water it is possible to determine the absolut temperature changes that occurs over a time interval.

\section{Silicates}

There is not much to say about silicate rninerals in the Norwegian caves as long as they are mainly clays, usually transported as clastic sediments and hardly correspond to the definition of speleothems and cave minerals that always formed after the development of the cavities. We identified in our samples: quartz, muscovite, orthoclase, tremolite, kaolinite and palygorskite. The presence of these rninerals is due either to weathering processes of mica schist and of marble (i.e. authigenic wheathering residues) or because they were carried unchanged into the cave from outside (allogenic residues).

We found them associated with manganese oxides and calcite speleothems as well. Any of these mentioned silicate minerals do not form speleotherns themselves.

\section{CONCLUSIONS}

Mineralogically, the Norwegian caves we investigated contain 17 different minerals so far, assigned to four chemical groups. Although the best represented group is that one of oxides-hydroxides, the minerals found in it form very few speleothems (an exception 
being the ice and goethite) when compared with the great variety of speleotherns forrned by the minerals from the carbonates and sulphates group.

The extensive calcitic moonmilk deposits found in many caves from north of Norway prove that the underground microclimate (very cold and wet) is favourable to the deposition of this speleothem. The outlook of the microcrystals present in both calcitic and gypsum moonmilk highly depends on the local thermodynamic conditions.

The sequence of allogenic and authogenic residual minerals is well represented (6 species). Their importance arise from being a basic material which could provide, through its weathering, ions that can further react and form new cave minerals.

Because the human impact on the cave environment almost always leads to irreversible destruction and just sometimes (very rare) to useful changes (see our thenardite), we have to protect the underground world in which minerals, animals and fossils are extremly well preserved.

The present investigation was intended as a first identification and description of the cave minerals forming speleothems in few caves from northern Norway. Further work on this topic is required to answer questions of origin, depositional mechanisms and the way the cave environment has to be protected against any kind of outside influence, so that the cave microclimate will rest undisturbed.

\section{ACKNOWLEDGEMENTS}

Dr. Magne Tysseland and Mr. Egil Erichsen are gratefiully thanked for their help in XRD and SEM analysis. Thanks are due to Viorel Boghean for his help in the field work activity and to Dr. Lucretia Ghergari who gave useful advices.

\section{REFERENCES}

BERNASCONI R. 1975. Le mondmilch calcitique et ses formes cristallines. Stalactite, 25: 8-10. COMAN D. 1984. Le karst - payasage biogeochimique. Theor. Appl. Karst., Bucuresti, 1: 23-28.

DIACONU G. 1976. QueIques considerations sur la genese du mondmilch calcitique dans les grottes.

Trav. Inst. Speol. “E. Racovitza', 15: 207-210.

FORD D. \& WILLIAMS P. 1992. Karst geomorphology and hydrology. Chapmann \& Hall, 2nd ed.: 1-601.

HILL C.A. \& FORTI P. 1986. Cave minerals ofthe world. NSS, Huntsville, Alabama: 1- 238.

KASHIMA N. 1983. On the Wad-minerals from the cavern environment. Int. J. Speleol., 13: 67-72.

LAURITZEN S.E. 1991. Karst resources and their conservation in Norway. Norsk. geogr.Tidsskr. 45: 119142.

ONAC P.B. 1991. Contributions to the knowledge of the north Norway karst. Studia Univ. BabesBolyai, Geogr., Cluj, 36: 37-44.

ONAC P.B. \& FARCAS T. 1992. Le moonmilk des grottes de Trollkjerka et de Reshellarn Lavangsmarka, Nordland, Norvège). Trav. Inst. Speol. "Emil Racovitza", Bucuresti, 35: 133-137.

ONAC P.B. \& GHERGARI L. 1993. Moonmilk mineralogy in some Romanian and Norwegian caves. Cave Science 20: 107-111.

WHITE B.W. 1976. Cave minerals and speleothems. In: FORD T.D. \& CULLINGFORD C.H. (Eds). -The science of speleology. Academic Press, London. 